\title{
Answering Questions, Questioning Answers: Understanding Tradisi and Moderen in the Intellectual Process of Balinese New Music Creations
}

\author{
I Wayan Sudirana \\ Music Department, Faculty of Performing Arts \\ Institut Seni Indonesia Denpasar \\ Jalan Nusa Indah, Sumerta, Denpasar, Bali, 80235 \\ e-mail: humas@isi-dps.ac.id \\ *Corresponding author: sudirana.isi@gmail.com
}

Published: 1 July 2020

Cite this article (APA): Sudirana, I. W. (2020). Answering questions, questioning answers: Understanding tradisi and moderen in the intellectual process of Balinese new music creations, Malaysian Journal of Music, 9, 1-16. https://doi.org/10.37134/mjm.vol9.1.2020

\begin{abstract}
In Bali, compositional process in music was traditionally more intuitive than conceptual. The recreation of beauty in nature through musical expression and melodic ideas was and is still thought to be sufficient for many to form a musical repertoire. However, these examples may be perceived as naïve, straightforward, or simplistic expressions in comparison to newer styles of Balinese musical composition. This article discusses how the terms 'traditional' and 'modern' are understood by academic and non-academic Balinese artists (both musicians and composers alike), and the extent to which they influence the aesthetics of Balinese composers' musical creations. Initially, I examine the historical dimension of Balinese compositions with all of its challenges, considering the terms 'traditional' and 'modern' as important to the understanding of the development of Balinese musical creations. I explore some new works for gamelan by Balinese composers, and further address some of the problems that arise in the development of Balinese music. Senior Balinese musicians/composers believe that local wisdom provides the foundation of Balinese music while the assimilation of global culture allows young musicians to innovate and develop their music without abandoning their indigenous identity. Younger Balinese composers are not only accepting, recreating, and changing established traditional/older music and ideas, but are now developing deeper, more intellectual methods of composition, expanding possibilities, and individual creativity to new levels. Older music is part of a new musical construction tailored to the way that composers create their works.
\end{abstract}

Keywords: creativity, innovation, intellectuality, moderen, new music, tradisi

\section{Introduction}

American ethnomusicologist McGraw (2013) states that there has been a prolonged polemic amongst academic and non-academic musicians in Bali, that claims that modern choreographies and compositions carry 'the wind of fear' to 'destroy tradition' merusak tradisi. McGraw wrote,

In the background, a radio transmitted frequency 96.5, Radio Global Bali, and on a call-in discussion about Balinese dance, a long-time listener, first-time caller speaking in clear, urbanized Indonesian free of the usual peppering of Balinese complained that modern choreographies and compositions were threatening to 'break tradition' merusak tradisi (McGraw, 2013, p. 68).

The discussion on 'Global Bali Radio' is interesting because it involved not only musicians and composers, but also a wide range of art-loving communities as well as a diversity of ordinary people within the modern 
Balinese community. The discussion led to the argument that the presence of modern choreographies and compositions in general is directly disrupting the continuation of Balinese traditional arts. On the issue of merusak tradisi, Balinese musician and composer, I Wayan Gde Yudane, expressed his disapproval in the strongest terms with the existence of the very categories 'tradition' and 'modern' when used in the context of new musical creations. Yudane said the terms were actually illusory, unrelated to music-making and have a destructive effect on a composer's creativity. He claimed that the terms should be avoided with respect to the creation of new works, since they form a barrier to the development of new ideas by composers and choreographers who have exerted this power for decades. He likened their effect to a kind of intellectual constipation that serves the existing political/governmental order (Yudane, personal communication, May 2018).

After completing my studies in Canada and returning to Bali in $2013,{ }^{1}$ I encountered somewhat critical subjective comments from senior Balinese musicians regarding a new piece for gamelan that I had composed. ${ }^{2}$ The issue of merusak tradisi was indirectly expressed to me after the concert. ${ }^{3}$ Some of the senior musicians thought that I disobeyed pakem (traditional musical rules) in my composition. However, I fully understood the need to value the inherited musical traditions. Indonesian philosopher and literary critic Sumardjo (2000) states that traditional arts as living traditions are very rare, and artists as 'value-free' human beings deserve to care about the values of inherited art works (p. 338). Following this encounter with my own work, I began to consider several questions - how should Balinese composers and musicians engage this artistic inheritance? Should we use the elements of traditional artwork to create modern art? Should we continue the tradition of art as it was created within its original context? Should we interpret and give new values to our traditional art?

This article discusses how the terms 'traditional' and 'modern' are understood in the context of academic and non-academic Balinese musicians (both performers and composers), and the extent to which they influence the mindset of the Balinese composers' musical creations. The first part of this article will examine the historical dimension with all of its challenges. The investigation of the concepts of 'traditional' and 'modern' and how they are defined in contemporary Indonesian society is important to understanding the development of Balinese musical creations. This article will then go on to analyse new works for gamelan, and address some of the problems that have arisen in the development of Balinese music. Senior Balinese musicians/composers believe that local wisdom is a foundation while the assimilation of global culture allows young Balinese musicians to innovate and develop without leaving their indigenous identity.

\section{Tradisi vs Moderen}

Tradition is generally defined as a habit that has been carried out continuously for a long time and becomes part of the life of a group of people in the same country, culture, time and religion. Sudirana quoted that, "tradisi adalah adat kebiasan turun temurun dari nenek moyang yang masih dijalankan oleh masyarakat; penilaian atau anggapan bahwa cara-cara yang telah ada merupakan yang paling baik dan benar (tradition is a hereditary custom which is passed down from ancestors and still used by the community; the assessment or belief that existing methods are the best and correct ones)" (2019, p. 129). Both of these understandings usually underlie the mindset of the Indonesian people in literally understanding the meaning of the word 'tradition.'

The perception of 'tradition' as static or a non-continuous process of development is still an obstacle that may restrict creativity for most Indonesians. Composer and ethnomusicologist Dieter Mack, who has lived, studied, and taught in Indonesia since 1978, states:

For most Indonesians, awareness of its history is less of a continuous development process from time to time (understanding of linear development). Tradition is more like something that does not change (circular or even 'round' and without a dimension of time travel), something more static with absolute values. (Mack, 2001, p. 34)

Mack notes that many Indonesian musicians tend to be overprotective of their long-inherited habits. For him, Indonesian musicians should recognise when to protect their inherited habits. Are these practices still in accordance with today's environment? Do they continue to have useful values for the development of human civilisation?

Moderen comes from the Latin word which means 'now.' If we restrict our understanding to the literal meaning of the word, the scope of moderen becomes very narrow. Even though moderen in the 
broadest sense - in this case the word moderen has turned into an official term, 'modern', and it is used widely in formal and informal discourses-is a change in the system of civilisation that has gone through a long process. When did this change begin? This is rather difficult to trace because every civilisation has its own historical dimensions based on the social complexity of its people.

When viewed from the historical dimension of Indonesia, modernisation in Bali, can be said to have occurred after Indonesia's independence in 1945 or at the beginning of the emergence of the 'New Order' after the mass killings of 1965-66 (Vickers, 2005, pp. 142-168). This was a time when modern identity was somehow imported directly from Western countries after Indonesian independence (Supanggah, 2003). From this point onwards, everything began to be viewed in terms of its benefits, its ease of being attained by the community. 'Modern' came to signify being rooted in pragmatic thinking, considering scientific concepts based on theory and law. In other words, 'modern' was equated with being rational and expunging irrational beliefs.

In the 1930s the term 'modern' was adapted in the Indonesian language to moderen. At the same time, the the word traditie became tradisi. In Bali, the use of the term moderen was associated with the imagination of life outside the caste system that was put in place by the Dutch. That is, "Bali's modern subjectivity is a state that frees its people from colonial control and caste rule systems, links Western humanism and Indian theosophy, and demonstrates various kinds of inspiration within the modern Balinese society" (McGraw, 2013, p. 18). From the 1930s onwards, Balinese society has been influenced by Western life which emphasised equality and the social function of human beings, along with the application of religious doctrine and mysticism.

\section{Merusak Tradisi (Breaking Traditions)?}

The fundamental aspect to think about now is to return to the notion that the emergence of Balinese modern choreographies and compositions threatens the continuation of Balinese traditional art. What causes many senior Balinese academic artists to have this opinion? Is this merely an attempt to protect the continuity of traditional Balinese arts? Or is there another reason behind it? Simply speaking, does 'tradition' really mean an 'absence of changes'? How do most artists (and also intellectuals) understand tradisi? Is there a clear mapping in understanding tradisi and moderen?

All of these questions arise out of a misunderstanding that has been prevalent amongst young Balinese artists for decades. ${ }^{4}$ After graduating from Institut Seni Indonesia (ISI) Denpasar in 2002, I felt afraid to express, innovate, or just simply to start new things to forge my personal identity. This feeling of fear was also expressed by Putu Adi Septa Suweca Putra, one of the young composers who came to work seriously on new music for gamelan (personal communication, 25 February, 2018). There are many Balinese musicians and composers who now understand that tradition will always change. They understand the linear and historical dimensions of tradition, and this provides them with a visionary view. However, there still are Balinese musicians and composers who advance only by 'copying/accepting' and who embrace a circular paradigm for history, this perspective may result in confusion in deciding their next steps.

The influence of authority actually plays an important role in shaping the direction or development of tradition. There have been times when Indonesian government bureaucrats fear the influx of profound foreign influences. Most of these influences are considered by Indonesian government officals to be disrupting the continuity of traditional art forms. The bureaucrats state: "if this situation continues, our traditional arts will fade away." Contrastingly, Indonesian clarinetist and composer Hardjana answers this statement in a straightforward way, writing, "the traditional arts of a nation that have been pioneered for centuries will not die, unless the tradition is buried with his people" (Hardjana, 2004, p. 63). This dialogue provides context for the two different perceptions between national cultural (ruler/authority) and academic (practitioner) cultural observers. But both national authorities and cultural practitioners actually aim for the continuation of inherited cultural heritage.

Understanding the concepts and goals of modern art is an urgent matter. The realm of conceptualisation is indeed fraught. We cannot only say that the things we create are in accordance with our own will. In the area of conception, music is not only an intuitive thing that allows our minds to be unfettered to enjoy the beauty and sounds of nature, the singing of birds, or the leap of a frog, all of which are only translated into simple and natural expressions. Music, as a concept, is a portrait of a human and intellectual view of life, which is translated by measurable methods and experiments with clear directions to project the time with the music itself (Wayan Gde Yudane, personal communication, March 28, 2018). In Balinese 
music, we have inherited this mindset from the era of the emergence of the kebyar (flashy) style in North Bali, and it is a milestone in the modern era of Bali.

In the realm of tradition, people are accustomed and comfortable listening to (or witnessing) something they have inherited from generation to generation; something that has been agreed upon for decades. Their imagination has been directed to appreciate 'safe' artistic choices, and usually without knowing deeply the textual and contextual analysis of the arts. In the modern (new/recent) realm, by contrast, the creation of art often implies an updated consciousness. This often makes most audiences confused about how to enjoy contemporary modern art. On the contrary, today art (including music) is often associated with entertainment, which 'spoils' the listener's ears. In Sjukur (2012), Jero Wacik, the former Indonesian Minister of Tourism in the reformasi era (1998 until today) states:

[...] culture can bring in foreign exchange; so it's like merchandise. That is dangerous. Art is a materialistic need. For example, in Bali there are many tourists. Many performances are summarised because tourists don't have much time. If it is performed all night, the tourists will not enjoy it. In Solo (Central Java) there is also the short version of Wayang Kulit (puppet shadow performance), or it is called pakeliran padet. But, besides that, how do we preserve the tradition? Tradition is considered as wisdom that is no longer needed...today, people only want something easy/instant/practical. (p. 24)

Composer Slamet Abdul Sjukur echoes this assertion,

While the important part for most people is what can be held or seen, and if this view is still there, it remains difficult. During this time, art, including music, is nothing more than entertainment. As long as people still think about it that way, we are still an 'orphan.' We are oppressed by our ignorance if we still consider the art solely as entertainment. (Sjukur, 2012, p. 24)

What is the important part in projecting our art? Is art projected as a commodity in fulfilling materialistic needs? Or is art an identity that projects the intellectual values into the modern realm? Ironically, many cultural observers still have an opinion that tends to 'dwarf' the conceptual domain of art. Art is often regarded as merchandise to be sold to a consumer. Making art a valuable asset in the world of tourism is a natural thing. But whatever is done should go through stages of development with a clear vision. I am sure that Jero Wacik, with his expert staff, has considered this. But we must realise that Indonesia is actually facing a very heavy 'stream' of the impact of global world competition. Commercial culture (art) is deliberately raised as a powerful weapon of capitalists who have changed the mindset of people today. This is related to practical culture - that which is instant, easy, and can be manipulated in all circles. In this context, art seems to be a 'whore' of consumers' tastes. Meanwhile, in the realm outside of commercial art, art is created seriously and with visionary conceptualisation. This new form of art is often difficult to find a place within the environment built by the capitalists (Sjukur, 2014, p. 310). This is the dilemma that is often found in the Indonesian (Balinese) art scene today.

Traditional art (or that which is labeled tradisi), as previously stated, is sometimes easy to sell because of its naïve expressions. In response to the capitalist competition in this global era, government programmmes tend to emphasise the kearifan lokal (local wisdom) in the craft objects making procedures. (Comaroff and Comaroff, 2009; Picard, 1990). Traditional art is believed to be able to compete in a straightforward manner because it is considered part of national identity. In fact, in accordance with Sjukur's statement above, most of the steps taken by the government tend to present traditional art as an object that can be 'polished' or 'packaged' to fulfill the needs of the consumers. The motto of kearifan lokal seems to be a widely applied label meant to evoke the unique flavour of Indonesia's best-selling merchandise. However, art should be placed as a subject that can take advantage of the kearifan lokal motto to become the basic foundation for creating the arts with a thoughtful intellectual conception adapted to this new era.

According to Mack's research in Indonesia, contemporary is considered a standard form, a 'certain style' or 'freestyle': just as there is a general understanding of the term 'tradition' as something that cannot be changed. In other words, tradition (first point) is something that must be preserved and must not be changed or damaged. He concludes, "Therefore, it is not surprising that artists who want to develop a type of traditional music are often accused of 'destroying traditional values.' Even though they do not want to erase the existing ones, they just want to add something" (Mack, 2001, p. 34). From this statement, it is clear that there is a strong fear about the extinction of a tradition.

Things that are contemporary (second point) are interpreted as having a certain style, which is free, or even arbitrary. When viewed from the understanding of tradition as explained in the first point above, 
we are reminded of the awareness of the historical dimension of Indonesian society which tends to think of tradition as circular, even without the dimensions of traveling time (round). This is understandable because it is directly related to politics, tourism and power. The second point is based on ignorance of the understanding of the historical dimension of Westerners who view history from the perspective of linear progression (traveling from time to time). This is fatal, and a solution to improve this misleading mindset should begin to be considered.

\section{Reflecting on the Predecessors}

Bali has had great, modern and visionary artists since the 1920s who understood that tradition is a continuous process. These visionary artists included the late visionary painter I Gusti Nyoman Lempad, ${ }^{5}$ the sculptor Ida Bagus Njana, and the great composer I Wayan Lotring. ${ }^{6}$ Lempad and Njana were two artists who founded the Pitamaha Ubud, the organisation of artists facilitated by the Ubud palace, the painter Rudolf Bonnet, and Walter Spies. Both Lempad and Njana had a visionary mindset on the aesthetic patterns of painting and sculpture, which were born from the artists' own consciousness. The traditional puppet (wayang) paintings that were previously non-realist (Figure 1), were broken down and 'dismantled' by Lempad's persistence in utilising his own skill as a painter, imagination, and interpretations of Balinese philosophy of life. In Lempad's paintings, traditional wayang was transformed into a realistic form and realist vision as a Balinese human in the context of philosophy. The wayang figures drawn by Lempad tend to be thin and long, interpreting thematic daily life of Balinese, Hindu mythology, Ramayana, Mahabharata, and local legends (Figure 2).

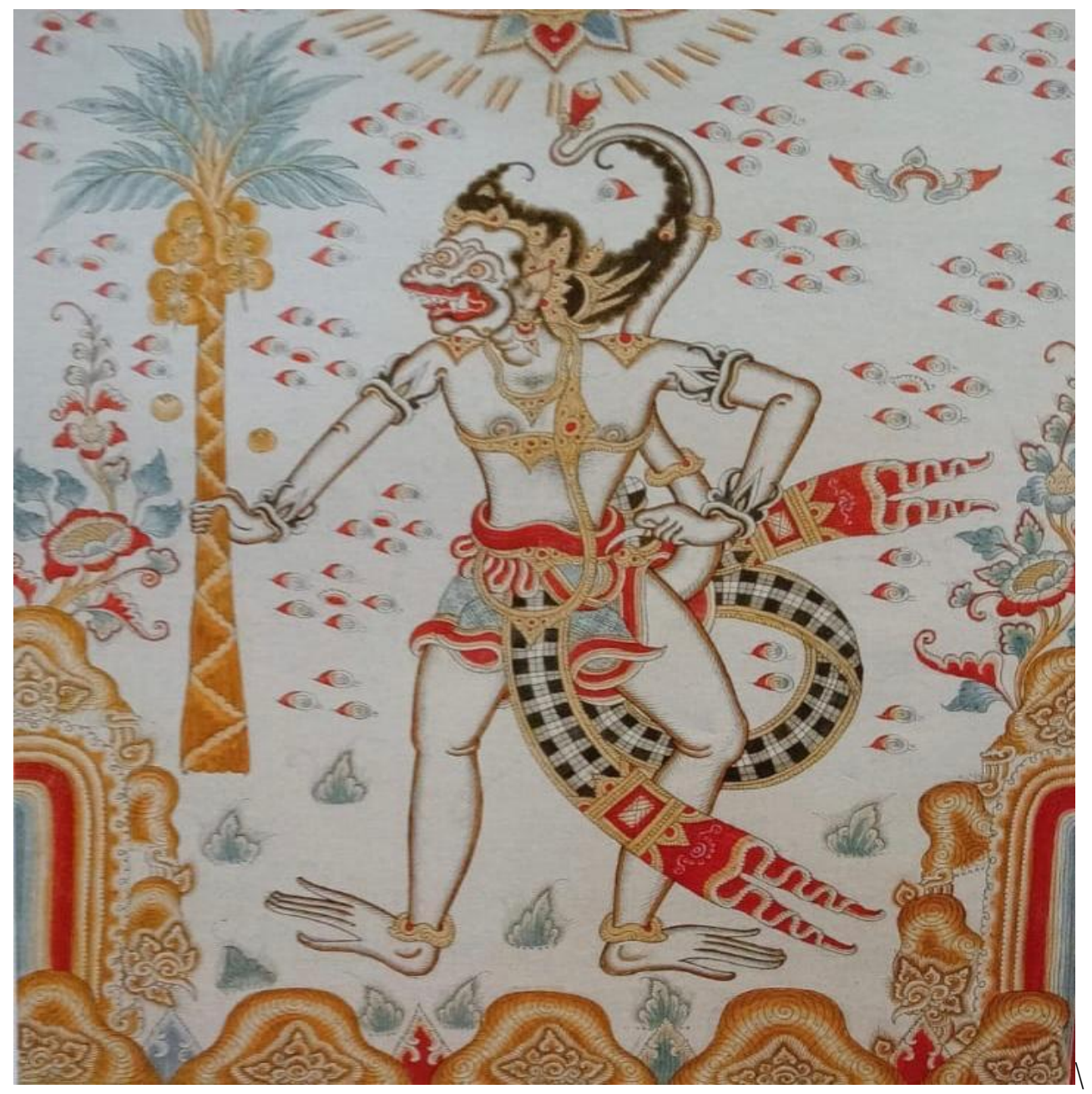

Figure 1. Traditional Wayang Painting (Source: I Gusti Made Bagus Putra Atmaja (Great Grandson of I Gusti Nyoman Lempad, 2019. 


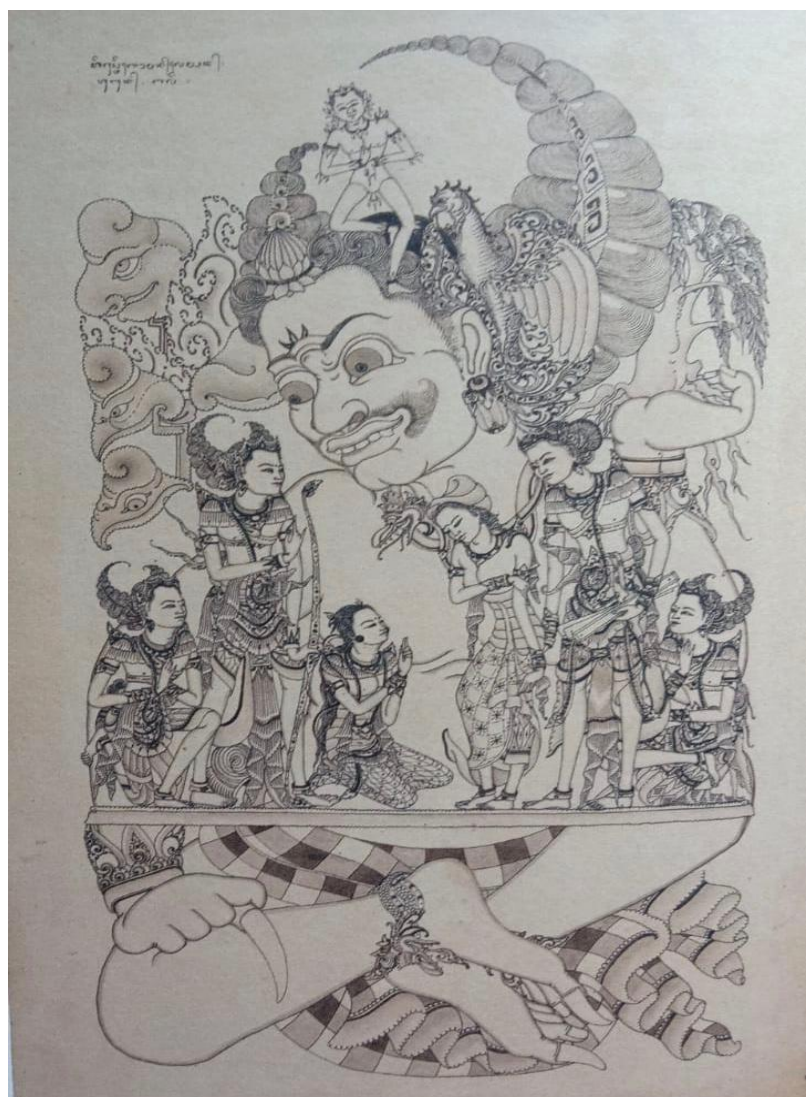

Figure 2. Work in Lempad's Style (Source: I Gusti Made Bagus Putra Atmaja, Great Grandson of I Gusti Nyoman Lempad, 2019).

Along with Lempad, the work of the late Njana evoked a specific concept related to this process: ape ade anggo (whatever is available in front of us, that is what we are going to use as an artwork). Thematic visualisation also inspired the work of Njana. The figures displayed in his sculptures adapt to the natural shape of the wood in front of him: if the available wood was large, the statue was adjusted to the anatomical shape of a human body at a larger scale. If the available wood was small and long, the resulting sculpture was a very thin and long statue, but the anatomical structure of the human body was perfectly visualised (Figure 3).

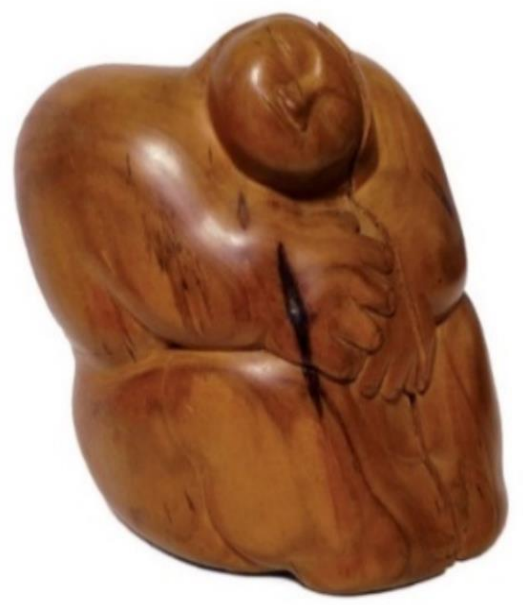

Figure 3. The sculpture of Ida Bagus Njana (Source: Ida Bagus Alit, the son of Ida Bagus Njana Tilem, 2018) 


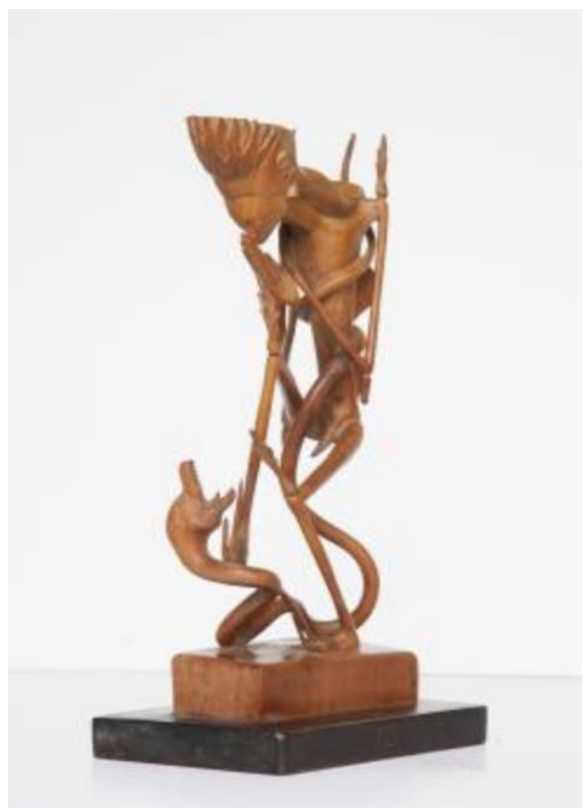

Figure 4. The sculpture of Ida Bagus Njana (Source: Ida Bagus Alit, the son of Ida Bagus Njana Tilem, 2018)

Lotring, a gamelan teacher and composer, presented patterns of kotekan (interlocking figurations) and unique or distinctive melodic progressions that are believed to have never been heard before. Lotring also proclaimed himself as the first composer for Balinese gamelan in the 1930s-something that individual composers had rarely done prior to him. Most of Lotring's compositions break the pakem (musical rules) of the traditional pieces, such as the pakem of legong (a court dance tradition) and lelambatan, (a traditional temple music), into a more expressive form and non-restrained melodic progressions in a free style. The structure of the pieces and melodic patterns from Lotring's compositions are mostly flexible with unpredictable dynamic and tempo changes, and the application of some odd meters in some transitions of the pieces. Because of these innovations, Lotring became a composer whose works have so far been respected not only in Bali, but also internationally.

How did Lempad, already have this mindset in the 1920s? Why do we, as the generation born in the era that is said to be the modern era, tend to experience stagnation or 'drought' of visionary and brave ideas that differ from what Lempad, Njana and Lotring did in their era? Indeed, there are times when stagnant conditions can occur at certain times. Nevertheless, will we just accept this stagnation and be resigned to only being a well-behaved audience?

An open mindset towards outside influences and the ability to assimilate these influences are the starting point of the restoration. Balinese artists are now expected to open themselves and occasionally selehin umahe uli disisi (see your house from the outside) - because when we get out of our own house that is where we can objectively see our house (Sudirana, 2013, p. 15). Lotring lived and studied in Surakarta for a few months. Arriving in Bali, he composed a song entitled 'Gonteng Jawa' (now popularly known as 'Solo'), with a Javanese melody integrated with Lotring's characteristic ornamentation. A visionary, open, and purposeful mindset is the path of hope that is awaited for today in addressing the development of Balinese new music in the era of globalisation.

While cultural and artistic conservatives argue that tradition requires protection from outside forces, some composers often reject classical specialisation and persistently defend the local traditions 'against' the modern with its universal and global values. A novelty that transcends innovation, similar to the global avant-gardism is considered to be found in its own territory, while ideas that are deemed sophisticated and advanced in the world of Western-style modernism may look like the ancient work commonly described in lontar (Balinese palm leaf writing or traditional scriptures). This statement emphasises that the global is not a hegemonic force and that only has the potential to destroy. We, as a generation of Balinese artists, must always assume that contemporary global culture will not only put pressure on and destroy cultures that are outside its path (Sudirana, 2013, p. 183). How can we understand what is 'tradition' and 'modern' using our own skill and intellectual abilities to address the progress of this fast-paced and sophisticated era? 


\section{Imaginasi and Nalar}

In 2006, senior composer Slamet Abdul Sjukur gave an analogy of the process of creativity in music:

If you wait for the command from your brain, in martial arts, you will lose the momentum or be hit first. Firefighters must move quickly without waiting for orders. It is a similar situation for the pick-pocketer. They should not hesitate when finding the right moment to act (personal communication, 2012, p. 12).

The process of creation starts from an intention to create, all the way through to the completion of the work. Sjukur reminds us to quickly respond to all forms of imagination that comes into our minds. Inspiration cannot be planned or designed. It comes suddenly. This is the case with composers. Composers need to be ready to process what they imagine into concrete musical forms using their experiences and technical skills. No matter how big the imaginings are, if the mind does not have sufficient ability to process them, no concrete musical ideas will be established.

The ability to process imaginings and inspirations into some patterned musical languages needs nalar, a logical reasoning of the composer: Nalar shapes imaginings of the unconscious minds into the concrete forms of musical ideas. As Yudane said, "Imaginings will not be able to form concrete musical ideas. We need 'nalar' or intellectuality, which leads the process of realising all forms of imaginations or inspirations" (personal communication, July 12, 2018). 'Nalar' for Yudane is the knowledge he has earned from developing his critical thinking, research and experiences in life. Knowledge is important in realising and organising ideas imparted into the unconscious mind.

Imagination also plays an important role in the creative process. Einstein and Shaw (1931) states that "Imagination is more important than knowledge. For knowledge is limited, whereas imagination embraces the entire world, stimulating progress, giving birth to evolution" (p. 31). This quote is precious and most people would agree with it. While we are nothing without knowledge, imagination is the source from which new knowledge springs. Yet, imagination is a waste if it is not transformed into something useful. It is like unlocking hidden doors that inventions lay behind; both play important roles in the human creative process.

Most Balinese academic composers at ISI Denpasar formally follow the four stages of creative processes set out by Wallas (1926): preparation, incubation, illumination, and verification. ${ }^{7}$ These stages became popular in expressing their creative processes on paper. They convey close cooperation between the conscious or rational/logical/analytical thinking brain (preparation and verification), and the subconscious or intuitive/imaginative thinking brain (incubation and illumination). Setiawan (2015), an Indonesian musician, critic and writer from Jogjakarta, states that intuitive thinking plays a prominent role in solving problems of composing music, not inferior to rational thinking. Intuition is responsible for 50-70 $\%$ of the creative process, while logical and cognitive considerations occupy the rest. In composing music, determining the proportion and the character of the work is far more important than just thinking systematically (pp. 39-43). Thinking systematically is akin to following standard instructions or compositional techniques, while intuition is the source of ideas for previously unknown compositional techniques. As Hardjana (2003) explains,

Great music can only be born out of talent, intelligence, and hard work. We know that inspiration is only a sprinkling of dew that spills on talent. That is not everything. Intuition, inner instinct and feeling is merely a determinant of intelligence. (p. 89)

Accessing both intuitive and rational (analytical) thinking in the creative process of composing is inevitable. Imagination and intellect always interact together in the musical experience, just as aesthetic considerations and intuition are always intertwined with artistic knowledge.

\section{Answering Questions, Questioning Answers: Composers' Methods}

Traditionally in Bali the compositional process in music was more intuitive than conceptual. The re-creation of beauty in nature through musical expression and melodic ideas was and still is enough for many to form a musical repertoire. For example, renowned senior composer Nyoman Windha argued that almost all of his works are based on intuitive exploration of the beauty of nature and the process of intuitively imagining melody and rhythm: 
The process usually begins with contemplation [imagining] in accordance to the selected theme [usually natural beauty]. These [imaginings] can happen at the beginning or when the work is realised. I usually write the music with or without initial themes. Everything is a result of contemplation. (personal communication, July 14, 2018)

One of his works entitled 'Wahyu Giri Suara', the first piece he composed for the gong kebyar competition, is claimed to be inspired by the abstract "celestial sound of the great mountain," with the exploration of new musical ideas at the time. Windha explains that wahyu means revelation or inspiration (also the name of his first-born child), giri means mountain, and suara means sound. According to Windha, with the intention to create new musical ideas, ironically, he started writing the music without clear musical concepts in mind. He followed the 'flow' while writing the music, depending on his experiences and direction of the beauty of nature perceived by his mind (personal communication, July 16, 2018). The source of his musical ideas was intuitive thinking. When investigating the conceptual process of transforming his intuitive thinking into a concrete form of musical ideas, Windha faced difficulties in expressing his concepts or analytical thoughts. His form may be perceived as intuitive, straightforward, or simplistic expressions in comparison to newer styles of Balinese musical composition.

For many contemporary Balinese composers, dissatisfaction with what has been obtained from the past and the need for change and new ideas is a reflection of cultural development. When questioned about how to compose, senior musicians typically respond, "It has always been that way" or "by seeking inspiration in nature." But young composers are no longer content with these responses and are questioning these answers. When questioning conceptual processes, that of music making, the image of the composer, is often intellectual and spiritual. However, Yudane states that those who wish to become composers must be aware that the composers are 'the condemned' - those doomed to an endless search throughout life; innovation is relentless (personal communication, July 12, 2018).

Most Balinese composers voice 'innovation' in composing new music. Innovation is usually linked to creativity and intellectuality. These two closely depend on how composers translate their intuitive thinking into concrete works - compositional works are actually intuitive works (Setiawan, 2015, p. 45). Windha's compositional processes also involve intuition, although he was consciously unable to break down his steps in composing. Balinese traditional composers usually have a passive knowledge. It can be argued that the combination of intuitive, spiritual, and intellectual thinking underlies the compositional processes of Balinese traditional composers.

Hardjana (2004) said that composers have confidence in their character, are mysterious, and full of curiosity and surprises. This leads them to always focus on subjectivity, uniqueness, and breakthrough - an important trilogy to measure the composers' personal responsibility (Setiawan, 2015, p. 47). Subjectivity is reasoning within the composers' mind, which absorbs all experiences and knowledge. From here, ideas are melted down and reconstituted into a concrete form of work by referring to uniqueness and breakthrough as the primary intention. Uniqueness is a quality of the composer's own identity, while breakthrough in composing is the innovation. Composing new music for gamelan for most Balinese contemporary composers requires subjectivity, uniqueness, and innovation. Moreover, technical skills, taste, and inspiration also play an important role in realising unique and innovative works. In other words, composers must formerly master the technical skills and optimise their musical senses, equipped with imagination, before being able to seamlessly perform compositional mechanisms.

\section{Komponis Kini}

In order to achieve the above-mentioned trilogy, Balinese contemporary composers often question the compositional theory acquired from their seniors; young composers are more critical of the answers that they learnt from elders or in school. One of the well-known traditional texts entitled prakempa has recently become an authoritative source of compositional theory and required text at the governmental collegiate arts conservatory in Bali. Prakempa maps the tones of Balinese scale systems (pelog and selendro) into the pengider bhuana, the concept of the revolving world or nine directions of the universe (Sudirana, 2019, p. 128). Explanations in the Prakempa tend to be abstract and beyond human reasoning. 
As McGraw (2013) explains,

The prakempa revels in mystical taxonomy without ever explicating the exact relation between theory and practice. Music is presented as an aspect of the divine or an expression of its agency; gods express unique aesthetic preferences and are associated with specific ensembles and tunings. Syllables associated with pitches are imagined to be intrinsically rather than arbitrarily related to their meanings. (p. 116)

Young composers privately question the nature of the text. They do not understand when professors direct them to use prakempa as a compositional tool. For young composers, the theory elucidated in prakempa is irrelevant to their practical experiences in gamelan.

As they were not satisfied with the responses they received, contemporary composers continuously explore their unique identities and innovate based on their own self-exploration. With the belief that identity is innate and constructed, and with modern technology providing easy access to information, they are exposed to the wide range of world musical cultures and, directly or indirectly, form their own understanding of compositional methodology. These composers want to be 'true composers,' composers who dare to face challenges and seek their own identity and methods of innovations as opposed to the penata tabuh or music arrangers associated with kebyar and tradisi forms (McGraw, 2013, p. 125).

In 2016, a new movement entitled 'Komponis Kini' emerged in the Balinese compositional scene, held in 'Bentara Budaya Bali' (Kompas Gramedia Cultural Institution). ${ }^{8}$ This movement was conceived as an attempt to give new formats, meanings and re-interpretations of classical and existing music, in addition to forming entirely new musical creations. This event is open to young composers to pour out their thoughts in composition. Together with the curators I Wayan Gede Yudane, Dewa Alit, and myself, this event became the only music event that focused entirely on the musik baru untuk gamelan (new music for gamelan) movement in Bali.

'Komponis Kini' is a planned and sustainable educational event and also a 'contest arena' of new ideas for young composers. This planned and sustained effort is intended to not only provide enlightenment, but also to share appreciation for the community to celebrate new art forms with high quality artistic achievements. 'Komponis Kini' is also an arena for new gamelan composers to express their latest achievements that reflect the authenticity of their creative journey. In addition to musical performances, the events are also enriched with post-performance dialogues with the composer as an educational forum for learning about the new works and discussing their methods of creation

The mission of Komponis Kini is to contemplate the future music of Balinese gamelan today. In other words, Komponis Kini provides a place in facilitating young composers to developing their creativity and search for their own unique identity. Komponis Kini is also a place for discussion and showing appreciation for these arts, and ideally it serves as a birthplace of new ideas in music for the gamelan. The boundaries of musical creativity are not limited by textual or contextual barriers, but they are located at the intellectual level of the composers themselves. The staging format is designed not only to display music works, but also to present the conceptual theories behind the work. From here, a discussion is opened after the performance as an opportunity for critics and corrections from audiences.

The first Komponis Kini was held every month from the beginning until the end of the year 2016 by presenting selected young Balinese composers. These selected young composers include: Sang Nyoman Arsa Wijaya (Denpasar, South Bali), Wayan Diana Putra, Putu Adi Septa Suweca Putra, Anak Agung Bagus Krishna (Gianyar, the middle part of Bali), Putu Gede Sukaryana (Tabanan, the west part of Bali), etc. They performed new works in their respective formats and responded to visionary composing methods of the legendary Balinese composer, I Wayan Lotring — the theme of first Komponis Kini event was Tribute to Lotring.

The curators of Komponis Kini also have the opportunity to perform their works in the event. This was held in the three-consecutive month finalising the event. I presented my own work entitled Kasus Lima, Dewa Alit presented a new work entitled 'Ngejuk Memedi', and Wayan Gede Yudane presented Journey. These three composers-curators explore all forms of possibilities to organise the pitches, rhythms, intervals, Balinese laras (modes), dynamics, and rasa (musical senses/feelings). My own Kasus Lima raises five issues presented coherently in the piece: experimenting with reng or the sustainable notes, exploitation of polyrhythmic structure, pitch range availability within the new gamelan, organisation of uneven meters, and the equality of instrumental functions. Kasus Lima was staged using a gamelan called Yuganada, a brandnew gamelan that I built myself. This gamelan gives a wider pitch range compared to the traditional gamelan: three octaves on each instrument. ${ }^{9}$ 
In the work entitled Ngejuk Memedi, Dewa Alit changes the perceptions and feelings of listeners by deliberately expanding the tuning system in his own gamelan Salukat. Alit rearranges the scale and tuning by following his intellectual taste combining (or processing) the possibility for a gamelan scale featuring eleven new pitches: the metallophone (gangsa) and suspended gongs (reong) are divided into two sets that have different pitch arrangements. This is done for the purposes of Alit's own compositional needs by looking for a vertical (top-down) pitch interval relationship to produce a new and distinctive combination of heterophonic combinations of traditional gamelan.

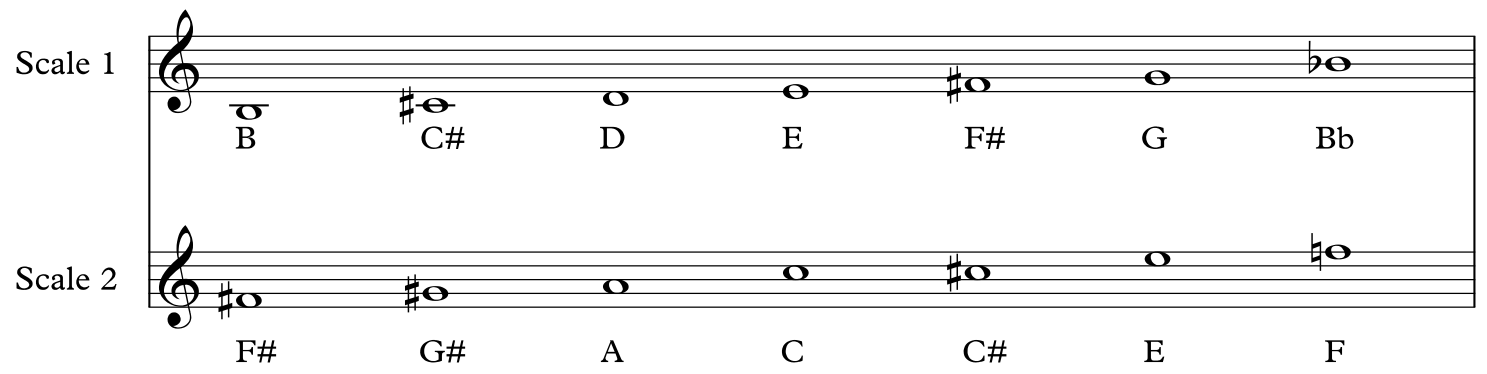

Figure 5. Two 7-tone Scale System of Gamelan Salukat

Figure 5 shows Alit's 11-tone system: a combination of two 7-tone scale systems. There are three tones that are shared (F\#, C\#, and E), and four independent ones on each scale: B, Bb, D, and G on scale 1, and $\mathrm{G \#}, \mathrm{A}, \mathrm{C}$, and $\mathrm{F}$ on scale 2. The reference of this tuning is the 12-tone tempered Western tuning system but it is deliberately tuned according to a Balinese traditional procedure. The instruments in gamelan Salukat are divided into two groups: half is tuned to scale 1, and the other half is tuned to scale 2 . These two different tuning systems are often used independently and sometimes together. The two scales produce a unique sound that differs from other Balinese gamelan in general.

Alit uses a layout combination of both cipher and Western notation for 'Ngejuk Memedi' (Figure 6). The numbers represent the pitches of the two scales mentioned earlier and are placed vertically and horizontally. This allows him to clearly see all of the layers of musical patterns for every section of the piece.

Ngejuk means 'chasing', and Memedi means an 'astral creature'. 'Ngejuk Memedi' is an analogy to the creation of new music that felt like looking for something astral, invisible, intangible, and can only be communicated by people who understand the astral world: reimagining the future of new music for gamelan. The unique and special tuning system of gamelan Salukat allows Alit to explore unusual possibilities of pitch arrangements. In other words, the two scales, when they are combined or played together or even when they are played separately, already sound unusual compared to the traditional Balinese scale system. Furthermore, the use of uneven meter throughout the piece adds a new flavour and an unusual feeling for the listeners. 'Ngejuk Memedi' displays ideas of polyrhythm, stratified melodies, and interwoven layers. ${ }^{10}$

Recalling Slamet Abdul Sjukur's analogy above about the process of creativity reflects a clear and systematical methodology in any given situation. Composers have to be ready to put down ideas and systematically transform them. Putu Adi Septa Suweca Putra (ala Kuprit), a young multi-talented musician and composer, explained, "ide-ide bisa saja datang secara tidak terduga, kapan saja, dan dimana saja." (ideas come in unexpected ways, anytime, and anywhere) (personal communication, July 12, 2018). These ideas, for Kuprit, come in abstract form. He then compiles and assimilates them into more concrete forms of musical elements. Experiences as a music appreciator and knowledge and understanding of other musical cultures (or composers) methods are the key to success. Discovering a unique and innovative approach to creating melodies, rhythms, harmonies, elaborations, etc. depends on, and are limited to the composers' own nalar. From there, new musical creations for gamelan generate their own authenticity: subjectivity, uniqueness, and breakthrough. 


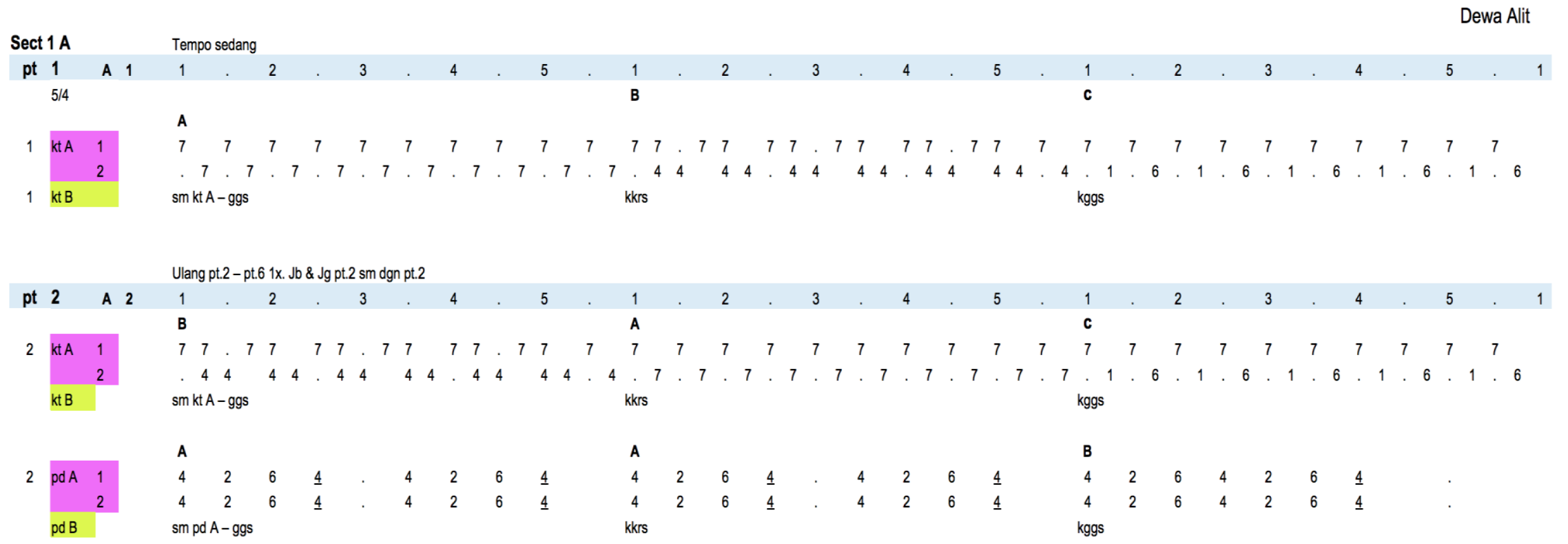

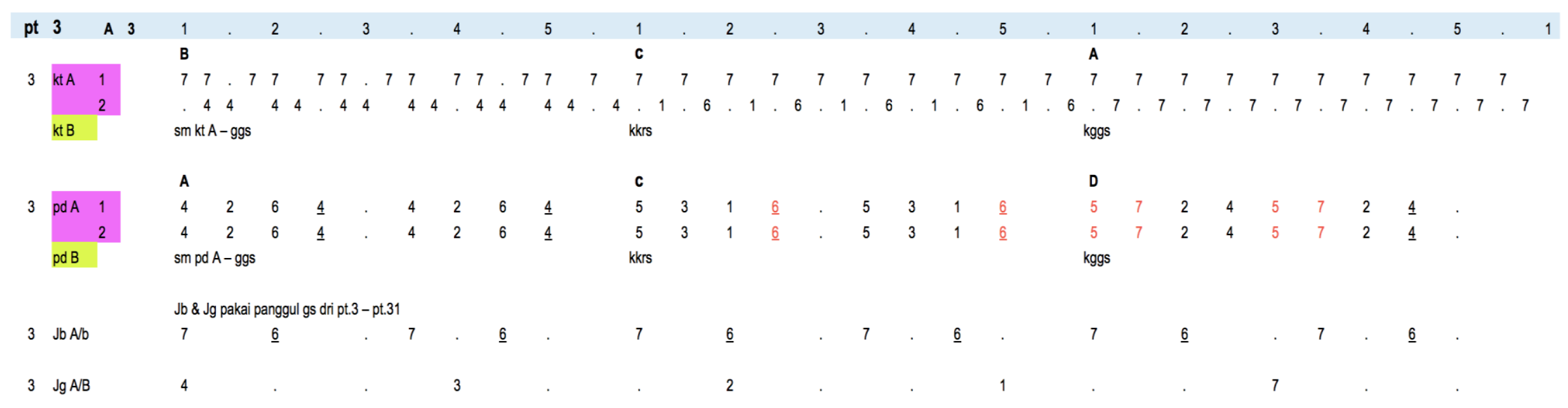

Figure 6. Sample of Ngejuk Memedi Notation by Dewa Alit 
As stated above, one of the pieces premiered at the Komponis Kini event was entitled 'Journey', a new form of music for gamelan composed by Yudane. Yudane has garnered a reputation for his breathtakingly diverse music, cutting across Balinese gamelan, western string ensembles, electroacoustic performances, choir, film, art installation and theatre. He has created pieces for ensembles as diverse as 'The New Zealand Trio'; 'New Zealand String Quartet'; 'Australian Art Orchestra' and 'Theft of Sita'; gamelan ensembles such as 'Gamelan Wrdhi Swaram' and many more. His composition embraces an open exploration of new ideas, crossing musical and cultural boundaries and referencing both Eastern and Western traditions. In his compositions, often characterised as fast moving, sweeping soundscapes, he continually experiments and explores the creative processes of new music.

Yudane introduces the concept of a new gamelan orchestra with a truly new achievement; utilising the space of silence, and breathing in rhythm with the music to create musical union. Thus, for Yudane, the Balinese gamelan succeeds in becoming an art form that continues to live and breathe with the 21st century. Yudane's works are result of creatively exploring a wide range of new musical creations to enrich the possibility of gamelan music, and reflect the courage of the creator to address something that has been standardised and traditionalised, in order to give birth to original (authentic) work.

Yudane makes comparisons between his work and Feldman's music as well as the gamelan tradition of Central Javanese gamelan, with the soft and very slow melodies revealed in the first part of this piece (Figure 7). This concept utilises elasticity: stretching time, tempo, and sonority (Morton Feldman, personal communication, July 12, 2018).

Responding to the waves/vibrato in the concept of ngumbang-ngisep (the higher and lower frequencies of paired pitches) in 'Gamelan Semarandana', ${ }^{11}$ he creates a meditation space where the pitch organisation of the melody is connected in the mind of the listener. The first part of the piece is marked at various points with a soft beat on jegogan (the bass metallophone). He also added floating tones and a flute (see figure 6: bar 7 to bar 21) that created an aural 'halo,' while kantilan and pemade (high-pitched metallophones that elaborate the core melody) added elements of nervous squeaks and suggestive tremolos. He feels that these subversive sounds are meant to prevent the work from becoming too flashy or 'precious.'

Traditionally, Balinese music has been known for ostinato elements as the basis for its music (Bandem, 2013; Dibia, 2017; Gold, 2005; McPhee, 1966; Sudirana, 2013a; Tenzer, et al. 2011 and Tilley, 2019). This is also a common element found in the music of numerous Southeast Asian traditions. Filipino composer José Maceda noted that:

"One unifying factor in the music of Southeast Asia is the element of repetition, which has become a musical form of itself, one which may be called drone, ostinato, or punctuation in solo instruments as well as complex ensembles including the gamelan and the pii phaad." (2007, p. 153)

Yudane works systematically in organising musical elements used in his piece. The element of repetition is somehow avoided. The selection of pitches, tempo, and rhythm is thoughtfully organised, and in accordance with the idea planned from the beginning; the intentions of melodic movements are fit to the specified theme. This is the result of Yudane's subjectivity in composing. The uniqueness of Yudane's compositions lies in the new form and structure of his pieces, the unusual rhythmic and melodic patterns of semarandana instruments, and the new function given to the standardised roles of each instrument within the ensemble.

Moreover, we are discussing a compositional method in an oral tradition, where music is traditionally passed down without the use of musical notation. The aural experience of performance interaction and groove is paramount. However, Yudane's breakthrough lies in the combination of the use of complete Western notation in writing and teaching his music and the synchronisation of bodies and groove in new kinds of interaction, resulting from the use of musical notation. This is a key achievement of this form of art music. 


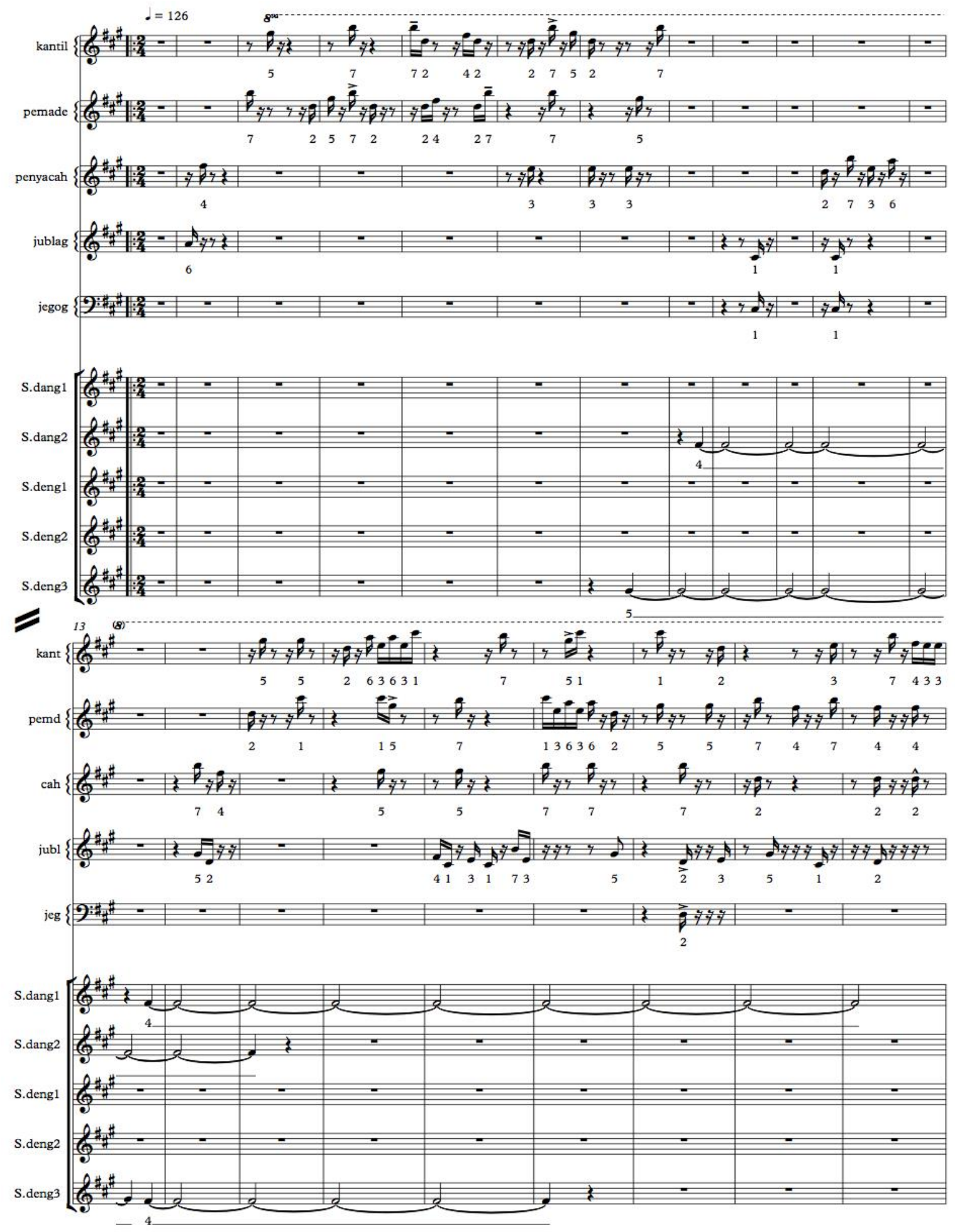

Figure 7. The first 21 bars of Journey by Wayan Gde Yudane

'Journey' is a piece that includes listeners beyond their expectation, and it breaks new territory with innovation and passion. Often this kind of music introduces new techniques for traditional instruments as well as presenting traditional instruments in new ways. This music challenges the traditional foundations of melody, rhythm, structure, dynamics, notation, timbre, length, size, and form. 


\section{Conclusion}

In the creation process of finding musical innovations, Balinese composers are overshadowed by a strong institutional intimidation in regards to the continuation of Balinese gamelan traditions. For many years, Balinese gamelan scholars have emphasized traditions over innovations. Old gamelan pieces have to be preserved, and new innovative works were labeled as ones that merusak tradisi (destroy tradition). Fearfulness of losing tradition is the main cause of this situation.

Understanding the meaning of 'tradition' in this situation is paramount. Murgiyanto (2004), a respected Indonesian scholar from Java, states "sesuatu yang diwariskan tidak berarti harus diterima, dihargai, diasimilasi atau disimpan sampai mati" (something that is inherited does not mean that it must be accepted, appreciated, assimilated or kept to death) (p. 2). The people who accept the inherited activities/material objects/beliefs/societies/phenomenon do not see them as inherited 'tradition.' The accepted 'traditions' are part of the people's daily lives. They have been maintained until now and have the same position as new innovations. With this understanding, tradition should not be placed against innovation. Tradition changes and develops, and it has to be placed in parallel to innovation.

Musical innovations in Balinese gamelan, especially by Balinese composers like Yudane, involve an intimate cooperation between the accepted, ongoing traditions of compositional methods and a new flourishing/innovative compositional method. Both require 'imagination' and 'intuition' as an initial compositional process. The difference is whether the composers actively or passively understand the imagination and intuition. Yudane introduces two terminologies in addressing new compositional method: 'productive imagination' and 'intellectual intuition.' Yudane stated that 'intuition is the presentation of imagination, and the development of the concept of 'productive imagination' to explain the actual art creation. Whereas 'intellectual intuition' is an object of reason that can be accounted for and not human cognition" (personal communication, December 12, 2018). By transforming this transcendental concept into cognitive exploitation and explaining all cognition experience. Therefore, the role of the productive imagination lies in the artistic creation of new artworks, and the role of intellectual intuition, as a form of productive imagination, lies in the scientific discovery of the new scientific hypotheses. In pragmatic epistemology, artists use their productive imagination differently to build various ways of representing reality.

\section{Endnotes}

${ }^{1}$ I completed a Master's degree (2009) and a PhD in Ethnomusicology (2013) at the University of British Columbia Canada under the supervision of Professor. Michael Tenzer.

2 I composed a piece for the 'Gamelan Gita Asmara Bali' tour, called 'Bhaskara.' The piece adapted traditional music system and developed it into a new work.

${ }^{3}$ Gamelan Gita Asmara, the Canadian-based gamelan group, performed at the 'Nretya Mandala' stage of Institut Seni Indonesia, (ISI) Denpasar as part of their Bali Tour in 2013. Most of Balinese master musicians and teachers were invited to watch the performance.

${ }^{4}$ This is based on my own experience as a Balinese student, musician, and composer, and also my recent research in this topic.

${ }^{5}$ Examples and information about Lempad can be found on YouTube: https://www.youtube.com/user/lempaddotnet

${ }^{6}$ Examples of Lotring's compositions can be found on YouTube:

https://www.youtube.com/channel/UCZgHkO8KFeqGaEiJsYih43A

${ }^{7}$ This is based on my experiences in studying at Institut Seni Indonesia (ISI), Denpasar from 1998 to 2002, and also teaching from 2014 until now.

${ }^{8}$ Bentara Budaya is a cultural institution of Kompas Gramedia, which means cultural messenger. As cultural envoys, Bentara Budaya accommodates and represents the nation's cultural developments, from various backgrounds and horizons, which may be different. The institution seeks to display cultural forms and works that may have traditionally been created or popular and populist art forms, as well as new works that seem to have no place and do not deserve to appear in a respectable building. Bentara Budaya serves as a meeting point between existing aspirations and growing aspirations (Warih Wisatsana, the director of Bentara Budaya Bali, personal communication, August 7, 2018).

${ }^{9}$ A full recording of Kasus Lima can be found on YouTube: https://www.youtube.com/watch?v=SqNv9oqlF-c

${ }^{10}$ Excerpts of 'Ngejuk Memedi' can be found on YouTube: https://www.youtube.com/watch?v=-p4dZSVjqOw 
11 'Gamelan Semarandana' is a new type of gamelan introduced around 1980 by the most respected Balinese gamelan guru, I Wayan Beratha. The gamelan combines the five-tone gamelan gong kebyar and the seven-tone gamelan samara pegulingan.

\section{References}

Bandem, M. (2013). Gamelan Bali di atas panggung sejarah. BP Stikom Bali.

Comaroff, J. L. and Comaroff, J. (2009). Ethnicity, Inc. University of Chicago Press

Dibia, W. (2017). Kotekan: Dalam musik dan kehidupan Bali? Bali Mangsi Foundation.

Einstein, A. \& Shaw, G.B. (1931). Einstein on cosmic religion and other opinions and aphorisms. CoviciFriede, Inc.

Gold. L. (2005). Music in Bali. Oxford University Press.

Hardjana, S. (2003). Corat-coret musik kontemporer dulu dan kini. Ford Foundation \& Masyarakat Seni Pertunjukan Indonesia (MSPI).

Hardjana, S. (2004). Musik antara kritik dan apresiasi. Penerbit Buku Kompas, Kompas Media Nusantara.

Maceda, J. (2007). A concept of time. Arcana II musicians on music. Hips Road.

Mack, D. (2001). Musik kontemporer dan persoalan interkultural. Artiline, Jalasutra Offset.

McGraw, A. C. (2013). Radical traditions reimagining culture in Balinese contemporary music. Oxford University Press.

McPhee, C. (1966). Music in Bali: A study of form and instrumental organisation in Balinese orchestral music. Yale University Press.

Murgiyanto, S. (2004). Tradisi dan inovasi beberapa masalah tari di Indonesia. Wedatama Widya Sastra.

Picard, M. (1990). Cultural tourism in Bali: Cultural performances as tourist attraction, Indonesia, 49, 37-74.

Setiawan, E. (2015). Serba-serbi intuisi musikal dan yang alamiah dari peristiwa musik. Art Music Today.

Sjukur, S. A. (2012). Virus setan: Risalah pemikiran music Slamet Abdul Sjukur. Art Music Today.

Sjukur, S. A. (2014.) Sluman slumun Slamet: Esai-esai Slamet Abdul Sjukur. Art Music Today.

Sudirana, I. W. (2013). Borrowing, stealing, and transforming: Cross cultural influences in Balinese neo traditional composition. In Stepputat, K. (Ed.), Performing arts in postmodern Bali: Changing interpretation, founding tradition (pp. 165-185). Shaker Verlag.

Sudirana, I. W. (2013a). "Gamelan Gong Luang: Ritual, time, place, music, and change in a Balinese sacred ensemble [Doctoral Thesis, University of British Columbia]. https://open.library.ubc.ca/cIRcle/collections/ubctheses/24/items/1.0071979

Sudirana, I. W. (2019). Tradisi versus modern: Diskursus pemahaman istilah tradisi dan modern di Indonesia. Mudra Jurnal Seni Budaya 34(1), 127-135.

Sumardjo, J. (2000). Filsafat seni. Institut Teknologi Bandung.

Supanggah, R. (2003). Campur sari: A reflection. Asian Music 34(2), 1-20.

Tenzer, M., Moja, I. M., \& Tenzer, M. (2011). Balinese gamelan music. Tuttle Publications

Tilley, L. (2019). Making it up together: The art of collective improvisation in Balinese music and beyond. University of Chicago Press.

Vickers, A. (2005). A history of modern Indonesia. Cambridge University Press.

Wallas, G. (1926). The art of thought. Solis Press.

\section{Biography}

I Wayan Sudirana, born in Ubud, Bali, is one of Bali's most renown musicians and composer. He teaches and performs across Bali and internationally. He is a professor at the Indonesia Institute of the Arts in Denpasar. After graduating from the Indonesian Arts Institute, Denpasar, he studied at the University of British Columbia (UBC) where he received his MA and $\mathrm{PhD}$ in Ethnomusicology. He was commissioned by the Canadian government to perform at the 2010 Winter Olympics in Vancouver, Canada. He also performed at the opening ceremony of the Asian Games held in Jakarta in August 2018 and Carnegie Hall, New York in 2008. He has published a book about the future of Balinese sacred ensemble (2019), and recently produced three CDs of his new works for Gamelan with Gamelan Yuganada (2019 and 2020). His current research is focused on the development of new music in Bali. 